\title{
Thermographic and anthropometric assessment of electrical stimulation on localized body fat
}

\author{
Avaliação termográfica e antropométrica da \\ eletrolipólise na adiposidade localizada
}

\author{
Graciele Guimarães Pitelli Aroca, Larissa Granato Viana, Rafaela Ferreira de Araújo Costa, \\ Dalilia Schmildt, Ligia de Sousa*
}

Universidade Federal de Alfenas (UNIFAL), Alfenas, MG, Brazil

\begin{abstract}
Introduction: Adiposity is defined as the accumulation of energy reserves within the adipose tissue at specific body sites. Low-frequency electrical stimulation elicits lipolysis. When applied by insertion of needles into the dermis-hypodermis junction, it leads to a modification of the interstitial space, favoring metabolic changes and lipolysis. Objective: To investigate the effects of electrical stimulation on body fat localized to the abdomen and flanks. Methods: Randomized, controlled clinical trial consisted of two groups of women with body fat localized to the abdomen and flanks. The intervention group (IG) was made up of 9 women $( \pm 24,77$ years) who received ten sessions of electrical stimulation, whereas the control group (CG) was made up of 7 women ( $\pm 21,8$ years) who did not receive electrical stimulation. Perimetric, adipometric and thermographic data were collected before and after the intervention. Data were analyzed using the ShapiroWilk test, $t$ test, one-way ANOVA. The significance level was set at $p<0,05$. Results: There were statistically significant differences between the intervention and control groups in the assessment immediately following intervention (IG: $33.08 \pm 1.00$; CG: $30.83 \pm 1.5 ; \mathrm{p}=0.002$ ), 15 minutes following intervention (IG: 33.05 \pm 0.48; CG: $30.40 \pm 1.24 ; p<0.0001$ ) and at the endpoint (IG: $32.22 \pm 14.20$; CG: $30.53 \pm 1.34 ; p=0.005$ ) for the thermographic data. For the anthropometric variables, there were no statistically significant differences before and after treatment. Conclusion: Electrical stimulation evokes a significant increase in the temperature of the subcutaneous tissue.
\end{abstract}

Keywords: Abdominal Fat. Electric Stimulation Therapy. Lipolysis.

GGPA: undergrad, e-mail: graci.pitelli@gmail.com LGV: undergrad, e-mail: larissa-sgp@hotmail.com RFAC: undergrad, e-mail: rafaelinhacostacg@gmail.com

DS: undergrad, e-mail: daliliaschmildt@hotmail.com

LS: PhD, e-mail: ligiaunifal@gmail.com 


\section{Resumo}

Introdução: Adiposidade é o acúmulo de reservas energéticas no tecido adiposo, em regiões específicas. A estimulação elétrica de baixa frequência como geradora da lipólise, quando aplicada com agulhas inseridas na junção derme-hipoderme, gera modificação do meio intersticial, favorecendo as trocas metabólicas e a lipólise. Objetivo: Investigar o efeito da eletrolipólise na adiposidade localizada em região abdominal e de flancos. Métodos: Ensaio clínico controlado e randomizado constituído de dois grupos: grupo intervenção GI, constituído de 9 mulheres ( \pm 24,77 anos) com adiposidade localizada nas regiões abdominal e de flancos, que realizaram dez sessões de eletrolipólise; e o grupo controle GC, constituído de 7 mulheres ( $\pm 21,8$ anos) que não realizaram as sessões de eletrolipólise. Prévia e posteriormente à intervenção foram coletados a perimetria, a adipometria e a análise termográfica. Para análise dos dados foram utilizados os testes Shapiro-Wilk, teste T, teste One-Way ANOVA; considerou-se nível de significância de $p<0,05$. Resultados: Para os dados termográficos, observou-se diferença estatística entre os grupos intervenção e controle na reavaliação imediata (GI: 33,08 \pm 1,00; GC: 30,83 \pm 1,5; $p=0,002$ ), reavaliação

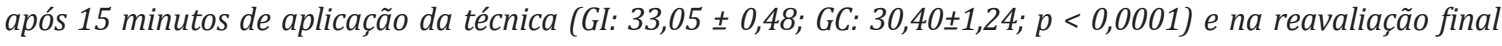
(GI:32,22 \pm 14,20; GC: 30,53 $\pm 1,34 ; p=0,005$ ). Para as variáveis antropométricas, não houve resultado significativo antes e após o tratamento. Conclusão: A eletrolipólise promove incremento significativo na temperatura do tecido subcutâneo.

Palavras-chave: Gordura Abdominal. Terapia por Estimulação Elétrica. Lipólise.

\section{Introduction}

Adiposity is defined as the accumulation of energy reserves within the adipose tissue. It is caused by caloric intake above the needed energy requirements for body metabolism. It refers to the excess of adipose tissue in the subcutaneous layer, known as adipose panicle, which stores $50 \%$ of the body fat. The adipose tissue is a differentiated connective tissue. It is formed by adipocytes, which have a thermal and filling function, and help in the maintenance of bodily structures and energy reserves $(1,2,3)$.

Adipose cells are remarkably diverse, depending on their site of concentration. Some cells are more efficient in the absorption of excess calories into the bloodstream, while others release their stored energy to other tissues. This explains the higher resistance of some fat deposits to reduction $(1,4)$. Adiposity gets stored in different regions of the body depending on sex, age, and metabolic, genetic, environmental and nutritional factors. Localized adiposity is not directly associated with obesity and can be present in nonobese individuals with fat accumulation in specific regions of the body (5).

Obesity is classified into android and gynecoid according to fat distribution and location. In gynecoid obesity, there is a greater amount of fat cells in the gluteal and trochanteric region, but mainly in the abdominal region, as seen in the women who participated in this study (5).
In the clinical setting, there are specific treatments that promote lipolysis at the application site (6). One of these resources is electrical stimulation, which uses needles as electricity conductors. Electrical stimulation has already been presented in the literature as a technique that can help reduce localized adiposity and edemas, improve metabolic response, stimulate nerves and vessels, and has anti-inflammatory, vasodilating, and, above all, hydrolytic properties $(7,8)$. The physiological effect of the application of the electrical current is explained by the activation of the sympathetic nervous system, which causes the release of catecholamines (epinephrine and norepinephrine). Catecholamines activate adrenergic receptors, leading to the release of adenylate cyclase and stimulating intracellular conversion of ATP into cyclic AMP, which brings about lipolysis (degradation of triglycerides into glycerol and fatty acids) (9).

The flow of electric current through the tissue generates an action potential difference between electrodes that is proportional to the electrical resistance of the tissue. This leads to an alteration of the permeability of the cell membrane due to the change of its polarization state. Additionally, the passage of electric current through the tissue elicits an increase in the temperature (Joule effect), inducing an anti-inflammatory and vasodilatory response. Increased circulation leads to increased cellular exchanges, nutrition, and elimination of toxins and fat degradation metabolites. 
The low-frequency current stimulates the fibrils of the connective tissue, improving skin tone (10).

Azevedo et al. (7) have measured localized abdominal adiposity using bioimpedance, perimetry and measurement of the abdominal fold before and after electrical stimulation associated or not with aerobic exercise training. They have found that electrical stimulation is effective in reducing body fat and waist circumference. Mello-Carpes et al. (11), in turn, have assessed the efficacy of percutaneous electrical stimulation in reducing the fat layer in the abdomen and flanks, by measuring the fat layer with the aid of ultrasound imaging and perimetric measurements. Their study has shown that percutaneous electrical stimulation was effective in reducing fat localized to the abdomen and flanks. We searched the literature in order to find studies on the physiological effects of electrical stimulation, but found no studies analyzing these effects by using infrared thermography. Thus, this study aims to investigate electrical stimulation using this technique.

Infrared thermography is a simple, safe and noninvasive method that allows the understanding of the physiology of the human body thermoregulation in different situations $(12,13)$. It displays an image based on the amount of heat (infrared radiation) emitted by the body (14). Skin thermography is widely used in physical therapy to assess various treatment resources $(15,16,17)$.

Despite the lack of statistical data, there is a great demand for aesthetic and dermatological-functional treatments in clinical practice $(2,3)$. Notwithstanding this demand, only a few treatments have been studied. There is a gap in the literature, especially with regard to the main stimulation parameters of electrical stimulation, which does not allow the performance of a procedure with adequate scientific support. There are only a small number of studies on this issue. It is therefore important to carry out studies to investigate the stimulation parameters of electrical stimulation, using objective measures such as skin thermography, in order to ensure its effective use in clinical practice.

This study aimed to investigate the effects of electrical stimulation on body fat localized to the abdominal region of young women, as well as the Joule effect of electrical stimulation regarding the increase in temperature and the consequent vasodilation and acceleration of the metabolism. In addition, it aimed to assess the anthropometric changes resulting from the treatments and compare them to the control group.

\section{Methods}

\section{Study Population and Sample}

This pilot, single-blind, randomized, controlled clinical trial was submitted to, and approved by, the Ethics Committee of the Federal University of Alfenas (UNIFAL), opinion number 508345. Prior to data collection, all volunteers were informed of the objectives and methods of the study, and agreed to participate in the trial. They all signed an informed consent form. The data were collected between April and June 2014.

Inclusion criteria were: being a female undergraduate student at the Federal University of Alfenas (UNIFAL, MG), aged between 18 and 30 years, Caucasian, and sedentary for at least the previous 2 months; having adiposity localized to the abdomen and flanks evidenced by a protrusion of the abdomen and flanks even during abdominal contraction while standing in the upright position; having normal vital signs (blood pressure = $120 / 80 \mathrm{mmHg}$, heart rate up to 100 beats per minute, and respiratory rate up to 20 breaths per minute), and with body mass index classified as normal weight (between 18.5 and $25 \mathrm{~kg} / \mathrm{m}^{2}$ ) or overweight (between 25 and $30 \mathrm{~kg} / \mathrm{m}^{2}$ ) (18).

Exclusion criteria were having already undertaken or being currently on dermatological-functional treatment to reduce localized adiposity; having cardiac or respiratory diseases, diabetes mellitus, hypertension or cancer; being unable to give a sensitive feedback or showing changes in skin sensitivity; and missing three consecutive days of treatment.

The participants were instructed to maintain their eating and exercise habits until completion of data collection.

Data collection procedures: Assessment and Treatment

Data were collected using an assessment form developed by the researchers, which contained the following items: age, body mass index, smoking habits, alcohol consumption, body shape, and presence of grade 1 geloid fibrous edema in the abdominal area. Prior to data collection, we measured the vital signs (heart rate, blood pressure and respiratory rate) of the participants. In case of changes, the subject would be excluded from the trial. 
Two researchers were involved in data collection: a main investigator (assessments) and an assistant investigator (intervention).

\section{Perimetry}

Perimetry was performed according to the standards recommended by GUIRRO and GUIRRO (2), to identify the location of fat distribution in the body, as well as changes in body shape using a measuring tape. The tape was placed on the skin surface, but not too tight fitting, on the umbilicus, two centimeters below the umbilicus, and two centimeters above the umbilicus. All measurements were performed by the same examiner (principal investigator).

\section{Adipometry}

Suprailiac and abdominal skinfold thickness were measured by lifting and folding the skin and fat with one's thumb and forefinger, detaching it from the muscle tissue. All measurements were performed three times, in the right hemisphere, with the subjects in the standing position. The result reported was the average of the three measurements (2).

Perimetry and adipometry were carried out before the first treatment session (baseline assessment) and after the last session (end point assessment). All measurements were performed by the same examiner (principal investigator).

\section{Infrared Thermography}

Thermal analysis was performed using an infrared camera (Flir Systems ${ }^{\circledR}$ ) with digital image processing, thermal sensitivity of $0.08^{\circ} \mathrm{C}$ and spectral range of 3 - 14 micrometers. We used the support software Velocity 2.3, with automatic calibration. The images were captured in a room with $22^{\circ} \mathrm{C}$ temperature (controlled by a thermometer), no sunlight and illuminated using cold light (fluorescent) bulbs. Participants were assessed in the standing position with the site of assessment free from clothing (13). The camera was positioned 1.2 meters away from the site of assessment, with the reference being the umbilicus.

Thermographic images were taken before (baseline assessment), immediately after (immediate assessment), 15 minutes after the first session (15 minutes assessment) and after the last session (end point assessment) for both groups. All thermographic assessments were performed by the same examiner (main investigator), and met all the predefined data collection criteria.

\section{Intervention procedures}

Volunteers were randomly divided into two groups. The Intervention Group (IG) attended two sessions of electrical stimulation per week, for five weeks (totaling 10 sessions) (7). Electrical stimulation was applied with the participant in the supine position, with the application sites free from clothing. First, the application site surface was sterilized with $70 \%$ ethanol. Then sterile needles $(0.25 \times 40 \mathrm{~mm})$ were inserted into the subcutaneous tissue using four channels: two channels on the right and two on the left below the umbilicus. In total, 8 needles were used per procedure. Needles corresponding to the same channels were positioned $6 \mathrm{~cm}$ apart from each other. Only sterile needles were used in the treatment sessions. After insertion of the needles, we used an electric stimulator $\left(\mathrm{HTM}^{\circledR}\right)$, "normal mode" TENS, a 40-minute application time, $30 \mathrm{~Hz}$ frequency, 250 microseconds pulse width and the participant's sensitivity threshold intensity (8). The entire treatment protocol was carried out by the same researcher (assistant investigator).

The control group (CG) consisted of volunteers who were monitored during the same period of time and met all the inclusion criteria, but received no treatment.

Figure 1 shows the flowchart of the study design and allocation of participants.

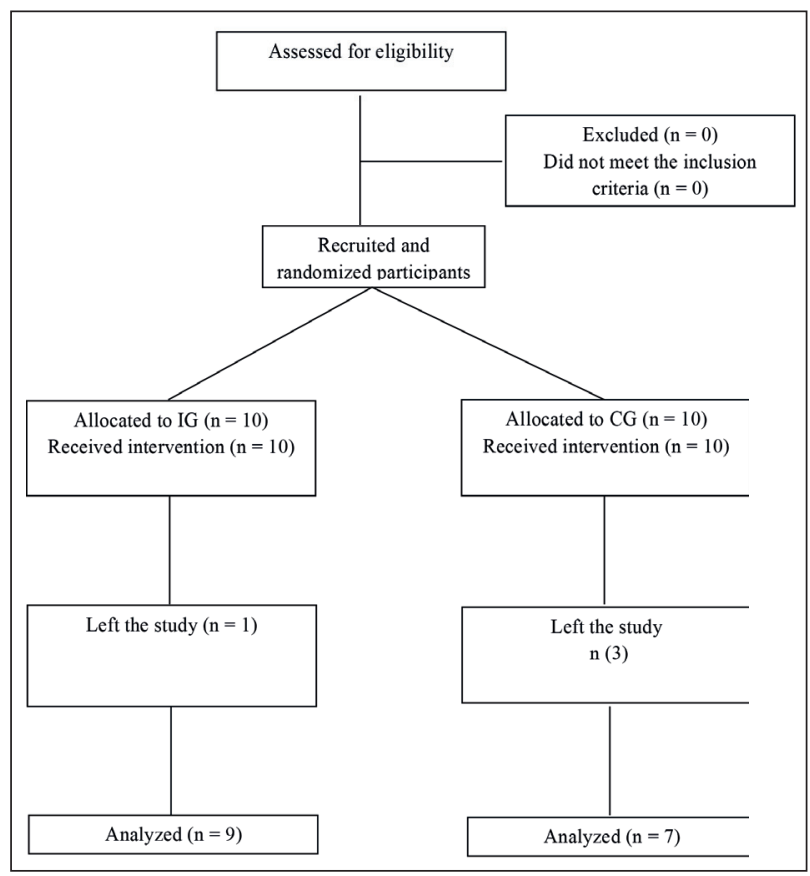

Figure 1 - Study design flowchart. 
Data processing and statistical analysis

For the analysis of the photos, the abdominal region was divided into four quadrants (two upper and two lower) using the umbilicus as the center point. The average value obtained from the four quadrants was used for data analysis.

We first performed a descriptive analysis to characterize the study participants. The sample was found to be normally distributed using the Shapiro-Wilk normality test, and then parametric tests were performed. We used the $t$ test to compare pre- and post-intervention perimetry, adipometry and thermography betweengroup data. Comparative intragroup analysis of the four thermography assessments was performed using paired $t$ test.

All data were analyzed using the statistical program SPSS (Statistical Package for Social Sciences) version 20.0. The significance level was set at $5 \%(p<0.05)$.

\section{Results}

The initial sample consisted of 20 volunteers who were divided into two groups: an intervention group $(I G=10)$ and a control group $(C G=10)$. However, as one participant from the IG and three from the CG decided to leave the study at some point, the final sample was composed of 16 participants (IG $=9$ and $\mathrm{CG}=7$ ).

The mean age of the sample was $24.27 \pm 4.59$ years $(\mathrm{IG}=24.22 \pm 4.9 ; \mathrm{CG}=24.33 \pm 4.24)$. The following clinical characteristics were analyzed: smoking habit, alcohol consumption, previous pregnancies, body shape, presence of abdominal geloid fibrous edema (GFE), and BMI. The values are depicted in Table 1. The t test showed that there were no statistical differences between groups; both groups were considered similar with respect to the characteristics analyzed. The anthropometric data related to pre- and postintervention suprailiac and abdominal adipometry, and waist circumference, abdomen and flanks perimetry are shown in Table 2. There was no statistical difference between the IG and CG regarding the decrease in abdominal measurements.
Table 1 - Clinical variables of the study population

\begin{tabular}{|c|c|c|c|}
\hline Variables & IG & CG & p value* \\
\hline Age & $24.77( \pm 5.09)$ & $21.8( \pm 1.3)$ & 0.84 \\
\hline BMI & $25.08( \pm 4.08)$ & $21.68( \pm 2.72)$ & 0.10 \\
\hline \multicolumn{4}{|l|}{ Smoker } \\
\hline Yes & $0(0 \%)$ & $0(0 \%)$ & 1.00 \\
\hline No & $9(100 \%)$ & $9(100 \%)$ & \\
\hline \multicolumn{4}{|l|}{ Drinker } \\
\hline Yes (socially) & 5 (55.6\%) & 5 (55.6\%) & 1.00 \\
\hline No & $4(44.4 \%)$ & $4(44.4 \%)$ & \\
\hline \multicolumn{4}{|l|}{ Body shape } \\
\hline Gynecoid & $6(66.7 \%)$ & $9(100 \%)$ & 0.68 \\
\hline Mixed & 3 (33.3\%) & $0(0 \%)$ & \\
\hline \multicolumn{4}{|c|}{ Grade 1 GFE in the abdominal area } \\
\hline Yes & $4(44.4 \%)$ & $3(33.3 \%)$ & 0.62 \\
\hline No & $5(55.6 \%)$ & $6(66.7 \%)$ & \\
\hline
\end{tabular}

Note: $\mathrm{P}<0.05$; Data presented as frequency and percentage. ${ }^{\star} \mathrm{t}$ test; GFE: geloid fibrous edema; BMI: Body Mass Index; IG: intervention group; CG: control group.

Table 2 - Pre- and post-intervention anthropometric data for both groups, regarding adipometry and perimetry of the abdominal area

\begin{tabular}{|c|c|c|c|}
\hline & $\begin{array}{c}\mathrm{IG} \\
\text { (mean and SD) }\end{array}$ & $\begin{array}{c}\mathrm{CG} \\
\text { (mean and SD) }\end{array}$ & $p$ value* \\
\hline \multicolumn{4}{|c|}{ Abdominal adipometry } \\
\hline Baseline & $35.45( \pm 6.95)$ & $25.58( \pm 8.95)$ & 0.68 \\
\hline End Point & $34.36( \pm 7.72)$ & $26.49( \pm 7.21)$ & \\
\hline \multicolumn{4}{|c|}{ Suprailiac adipometry } \\
\hline Baseline & $40.40( \pm 3.85)$ & $28.50( \pm 5.63)$ & 0.94 \\
\hline End Point & $40.44( \pm 8.93)$ & $\begin{array}{c}29.89( \pm \\
10.74)\end{array}$ & \\
\hline \multicolumn{4}{|c|}{ Waist circumference perimetry } \\
\hline Baseline & $83.83( \pm 12.94)$ & $73.40( \pm 5.94)$ & 0.51 \\
\hline End Point & $84.38( \pm 11.94)$ & $73.75( \pm 4.19)$ & \\
\hline
\end{tabular}




\begin{tabular}{lrrr} 
& & & (Conclusion) \\
\hline Perimetry on the umbilicus & & \\
Baseline & $89.66( \pm 12.65)$ & $78.80( \pm 6.68)$ & 0.32 \\
End Point & $89.57 \pm 12.87$ & $78.00( \pm 5.47)$ & \\
Flanks perimetry & & & \\
Baseline & $92.38( \pm 12.09)$ & $81.50( \pm 4.6)$ & 0.47 \\
End Point & $90.50( \pm 14.16)$ & $81.30( \pm 4.03)$ & \\
\hline
\end{tabular}

Note: $p<0.05 .{ }^{*}$ T test; IG: intervention group; CG: control group; Baseline: baseline assessment; End Point: end point assessment.

Thermographic findings are shown in Table 3. We found statistical differences between groups in all assessments after baseline, regarding the increase in temperature. There were statistical differences in the IG but not in the CG.

Table 3 - Pre- and post-intervention thermographic assessment data for both groups

\begin{tabular}{llll}
\hline & $\begin{array}{l}\text { IG } \\
\text { (mean and SD) }\end{array}$ & $\begin{array}{l}\text { CG } \\
\text { (mean and SD) }\end{array}$ & P value* \\
\hline Baseline & $31.85 \pm 0.74^{\mathrm{a}, \mathrm{b}}$ & $30.48 \pm 1.62$ & 0.47 \\
Imm.Ass & $33.08 \pm 1.00^{\mathrm{a}, \mathrm{c}}$ & $30.83 \pm 1.5$ & $\mathbf{0 . 0 0 2}$ \\
15mAss & $33.05 \pm 0.48^{\mathrm{b}, \mathrm{d}}$ & $30.40 \pm 1.24$ & $<\mathbf{0 . 0 0 0 1}$ \\
& $32.22 \pm$ & $30.53 \pm 1.34$ & $\mathbf{0 . 0 0 5}$ \\
\hline End Point & \begin{tabular}{l}
$14.20^{\mathrm{c}, \mathrm{d}}$ \\
\hline
\end{tabular}
\end{tabular}

Note: $P<0.05$. ${ }^{*}$ test; IG: intervention group; CG: control group; Baseline: Baseline assessment; Imm.Ass: Assessment immediately following intervention; 15mAss: Assessment 15 min following intervention; End Point: End point assessment. Intragroup analysis (columns): paired $\mathrm{t}$ test - intervention group: ${ }^{\mathrm{a}}=$ statistical difference between Baseline and Imm.Ass $(p<0.001) .{ }^{b}=$ statistical difference between Baseline and $15 \mathrm{mAss}(\mathrm{p}<0.001) \cdot{ }^{\mathrm{c}}=$ statistical difference between Imm.Ass and End Point $(p<0.001) \cdot{ }^{d}=$ statistical difference between $15 \mathrm{mAss}$ and End Point $(p<0.001)$.

Regarding the thermographic data, there were intragroup statistical differences between baseline and the assessment immediately following intervention $(\mathrm{p}<$ 0.001 ); between baseline and 15 minutes assessment ( $p$ $<0.001$ ); between immediate assessment and end point assessment $(\mathrm{p}<0.001)$; and between the 15 minutes assessment and the end point assessment $(p<0.001)$.

\section{Discussion}

Electrical stimulation elicits physiological changes in the adipocyte, evokes changes in the polarity of the cell membrane, activates microcirculation, and improves skin tone and lipolysis (19). The Joule effect elicits an increase in the temperature and contributes to an increase in local blood flow and vasodilation, contributing to an increased metabolism, the burning of calories and an improved cell trophism (9). The literature indicates that the temperature at sites with quantitatively higher amounts of fat tissue is usually lower than in other sites, so the use of certain resources is needed to stimulate blood flow and increase the metabolism in the area (20).

According to Guedes and Guedes (21), changes in body fat distribution are an important morphological indicator of endocrine and metabolic complications. Individuals with higher concentrations of fat in the abdominal area have a higher incidence of diabetes mellitus, hypertension and dyslipidemia. We opted therefore to apply electrical stimulation to the abdominal area.

It is believed that the increase in cutaneous temperature after the use of functional and dermatological physical therapy resources is one of the main mechanisms to improve body shape and to reduce measures of adiposity. This is because local heating facilitates the spontaneous output of triglycerides - as fatty acid and glycerol - from the cytoplasm of fat cells into the bloodstream (6).

A clinical trial whose objective was to analyze the behavior of fat cells in women undergoing electrical stimulation has found an increase in plasma levels of fatty acid and glycerol in the region close to the stimulated cells. This proves the release of such molecules and, consequently, the reduction in the volume of adipocytes in the body region that received the intervention (19, 22). Blood tests were not performed in the aforementioned study. They would have probably improved the results found.

The effectiveness of electrical stimulation using TENS has been confirmed by Araújo et al. and Assumpção et al. $(23,24)$. These authors claim that the stimulus generated by TENS devices was able to reproduce the same physiological effects as when classic electrical stimulation devices were used. This justifies the use of TENS in this study.

With regard to the application technique, Mello et al. (25) assert that it is applied by insertion of smalldiameter needles into the adipose panicle or through the application of electrodes to the skin surface. Parient 
(26), however, claims that thicker needles show higher effectiveness than small-diameter needles. The author suggests the use of 0.25 to $0.30 \mathrm{~mm}$ diameter stainless steel needles with a length variation of 1 to 12 centimeters. He also suggests that the needles are separated by more than 5 centimeters for improved coverage of the area to be treated. Assumpção et al. (24), on the other hand, asserts that the distance between needles should not exceed 10 centimeters in order to prevent the dissipation of current.

In this study electrical stimulation was performed with TENS, using 0.25 to $40 \mathrm{~mm}$ needles 6 centimeters away from one another, and at a frequency of 30 $\mathrm{Hz}$, in accordance with the aforementioned studies. Scorza et al. (8) have used the same current, frequency and distance between needles and found a reduction of abdominal fat in the area to which electrical stimulation was applied. This finding was not repeated in the anthropometric data from this study.

Azevedo et al. (7) have used electrical stimulation at the acupuncture points E21 (Liangmen), E23 (Taiyi), E25 (Tianshu) and E27 (Daju), together with 10 treatment sessions ( 2 sessions per week for 5 weeks). Participants were divided into two groups: Group one (G1) consisted of 5 subjects who only received electrical stimulation, while Group two (G2) comprised 5 subjects who received electrical stimulation and performed aerobic training. The eletrical stimulation device was set at a frequency of $15 \mathrm{~Hz}$, and the intensity was set according to the tolerance of the individual patient. There were favorable perimetry and adipometry results for both groups, and the most significant results were found for the G2. The study results have been optimized with the combined use of electrical stimulation and aerobic exercise, because the latter enhances tissue lipolysis and increases blood flow, thus increasing cellular activity and the excretion of cellular metabolites (27). In this study, however, no significant perimetry and adipometry results were found. It differs from the study by Azevendo et al. (7) in respect to the parameters used (frequency of $30 \mathrm{~Hz}$, pulse width of 250 microseconds and $40 \mathrm{~min}$ application time), and because we did not use acupuncture points nor aerobic exercising.

Mello-Carpes et al. (11) have also found positive results. Their study has shown the reduction of infra-umbilical and umbilical perimetry measures after treatment with percutaneous electrical stimulation using the HVS electrical stimulation device (KW, National Industry of Electronic Technology Ltd.), 4 pairs of needles placed in the abdomen and flanks area, the same frequency used in this study $(30 \mathrm{~Hz})$, and $50 \mathrm{~min}$ application time. The authors reported satisfaction with the new body shape acquired after using electrical stimulation (28).

In a study with 10 volunteers who received six sessions of electrical stimulation, Paula et al. (29) have also found a significant reduction in waist circumference (about 2\%).

According to Assumpção et al. (24) the adoption of a hypocaloric diet combined with aerobic physical activity can contribute to better treatment outcomes. In our study there was no such association because the participants maintained their eating habits and sedentary lifestyles, which has probably limited the results.

Most of the previous studies with electrical stimulation $(7,25)$ have used 10 treatment sessions and found positive results. We also used only 10 sessions and found positive results only in the thermographic assessment but not in anthropometric assessment. These data suggest that further treatment sessions could be conducted in order to enhance the effects of electrical stimulation and achieve better results with the use of this technique.

The different results found in the studies reported above may be associated with the use of different application techniques and stimulation parameters. Of note, the literature on this subject is still scarce. There are only a few randomized controlled trials with good methodological design. Thus, further studies on this topic are needed. The small size of the sample, the fact that some subjects left the study at some point, and the lack of studies and of standardization of current parameters are recognized as limitations of this study.

We recommend that further studies investigate the use of other current modulation parameters, as well as the complementation with other techniques, such as electrical bioimpedance, ultrasound imaging, among others, to assess the metabolic effects of the intervention.

\section{Conclusion}

We found that electrical stimulation evokes a significant increase in the temperature of the subcutaneous tissue. This results in an increased metabolism, and thus facilitates lipolysis. In the anthropometric assessment, however, there was no statistically significant differences before and after treatment. This is probably due to the small sample size. Thus, further studies are required to scientifically prove the effects of electrical stimulation on abdominal fat and improve the provision of evidence-based care. 


\section{References}

1. Feng B, Zhang T, Xu H. Human adipose dynamics and metabolic health. Ann N Y Acad Sci. 2013;1281:160-77.

2. Guirro E, Guirro R. Fisioterapia dermato-funcional. São Paulo: Manole; 2004. Portuguese.

3. Borges FS. Modalidades Terapêuticas nas disfunções estéticas. São Paulo: Phorte; 2010. Portuguese.

4. Jo J, Shreif Z, Periwal V. Quantitative dynamics of adipose cells. Adipocyte. 2012;1(2):80-8.

5. Lee M, Wu Y, Fried SK. Adipose tissue heterogeneity: implication of depot differencesin adipose tissue for obesity complications. Mol Aspects Med. 2013;34(1):1-11.

6. Mulholland RS, Paul MD, Chalfoun C. Noninvasive body contouring with radiofrequency, ultrasound, cryolipolysis, and low-level laser therapy. Clin Plast Surg. 2011;38(3):503-20.

7. Azevedo CJD, Zanin EC, Tolentino TM, Cepeda CC, Busnardo VL. Estudo comparativo dos efeitos da eletrolipólise por acupontos e da eletrolipólise por acupontos associada ao trabalho aeróbico no tratamento da adiposidade abdominal grau I em indivíduos do sexo feminino com idade entre 18 e 25 anos. RUBS. 2008;1(2):64-71.

8. Scorza FA, Figueiredo MM, Liao CO, Borges FC. Estudo comparativo dos efeitos da eletrolipólise com uso de TENS modo burst e modo normal no tratamento de adiposidade localizada abdominal. Ensaios e Ciência: Ciências Biológicas, Agrárias e da Saúde. 2008;7(2):49-62.

9. Soriano MCD, Pérez SC, Baques MIC. Electroestética profesional aplicada: teoria y práctica para la utilización de corrientes en estética. Barcelona: Editora Sorisa; 2000. Spanish.

10. Hamida ZH, Comtois AS, Portmann M, Boucher JP, Savard R. Effect of electrical stimulation on lipolysis of human white adipocytes. Appl Physiol Nutr Metab. 2011;36(2):271-5.

11. Mello-Carpes PB, Stumpf T, Piccinini AM, Rosa PV. A eletrolipólise percutânea como possibilidade de diminuição da adiposidade em abdomen e flancos. Biomotriz. 2012;6(2):94-104.

12. Bouzida N, Bendada A, Maldague XP. Visualization of body thermoregulation by infrared imaging. J Therm Biol. 2009;34(3):120-6.
13. Brioschi ML, Yeng LT, Pastor EMH, Colman D, Silva FMRM, Teixeira MJ. Documentação da síndrome dolorosa miofascial por imagem infravermelha. Acta Fisiatr. 2007;14(1).

14. Eddy AL, van Hoogmoed LM, Snyder JR. The role of thermography in the management of equine lameness. Vet J. 2001;162(3):172-81.

15. Sefton JM, Yarar C, Berry JW, Pascoe DD. Therapeutic massage of the neck and shoulders produces changes in peripheral blood flow when assessed with dynamic infrared thermography. J Altern Complement Med. 2010;16(7):723-32.

16. Holey LA, Dixon J, Selfe J. An exploratory thermographic investigation of the effects of connective tissue massage on autonomic function. J Manipulative Physiol Ther. 2011;34(7):457-62.

17. Gazerani P, Arendt-Nielsen L. Cutaneous vasomotor reactions in response to controlled heat applied on various body regions of healthy humans: evaluation of time course and application parameters. Int J Physiol Pathophysiol Pharmacol. 2011;3(3):202-9.

18. Brasil, Ministério da Saúde. Secretaria de Atenção à Saúde. Departamento de Atenção Básica. Orientações para a coleta e análise de dados antropométricos em serviços de saúde: Norma Técnica do Sistema de Vigilância Alimentar e Nutricional - SISVAN - Ministério da Saúde, Secretaria de Atenção à Saúde, Departamento de Atenção Básica. Brasília: Ministério da Saúde; 2011. Portuguese.

19. Maio M. Tratado de Medicina Estética. São Paulo: Roca; 2004. Portuguese.

20. Savastano DM, Gorbach AM, Eden HS, Brady SM, Reynolds JC, Yanovscki JA. Adiposity and human regional body temperature. Am J Clin Nutr. 2009;90(5):1124-31.

21. Guedes D, Guedes J. Distribuição de gordura corporal, pressão arterial e níveis de lipídios-lipoproteínas plasmáticas. Arq Bras Cardiol. 1998;70(2):93-8.

22. Paula MR, Picheth G, Simões NDP. Efeitos da eletrolipoforese nas concentrações séricas de ácido graxo e colesterol e do perfil lipídico. Fisioter Bras. 2007;11(87):43-7.

23. Araújo CP, Brito AKAT, Escarião AD, Torres RBA. Eletrolipólise como método de redução de adiposidade no abdome inferior: estudo piloto. Revista de Especialização em Fisioterapia. 2007;1(2). 
24. Assumpção AC, Souza A, Máximo L, Cardoso MC, Borges FS. Eletrolipólise (Eletrolipoforese). In: Borges FS. Dermato-Funcional: Modalidades Terapêuticas nas Disfunções Estéticas. São Paulo: Phorte; 2006. p. 217225. Portuguese.

25. Mello P, Dreher PM, Piccinini AM, Rosa LHT, Rosa PV. Comparação dos efeitos da eletrolipólise transcutânea e percutânea sobre a gordura localizada na região abdominal e de flancos através da perimetria e análise de bioimpedância elétrica. Fisioter Bra. 2010;11(3):198-203.

26. Parienti IJ. Medicina Estética. São Paulo: Andrei; 2001.

27. Douglas CR. Tratado de Fisiologia Aplicada à Saúde. São Paulo: Robe Editorial; 1999.

28. Machado GC, Vieira RB, Oliveira NML, Lopes CR. Análise dos efeitos do ultrassom terapêutico e da eletrolipoforese nas alterações decorrentes do fibroedema gelóide. Fisioter Mov. 2011;24(3):471-9.

29. Paula M, Pichet G, Simões N. Efeitos da eletrolipoforese nas concentrações séricas do glicerol e perfil lipídico. Fisioter Bras. 2007 Jan/Feb:5-9. Suplemento Especial.

Received in 12/16/2014

Recebido em 16/12/2014

Approved in 12/18/2015

Aprovado em 18/12/2015 
